\title{
Creep-rupture strength prediction of an epoxy composite under tension
}

\author{
R.K. Krastev • G. Zachariev • J. Hristova · J. Minster
}

Published online: 6 May 2009

(C) Springer Science+Business Media, B. V. 2009

\section{Erratum to: Mech Time-Depend Mater \\ DOI 10.1007/s11043-009-9077-x}

Unfortunately the captions for Figs. 2 and 3 are not correct; they should read:

Fig. 2 Diagram of short-term strength

and

Fig. 3 Creep of part of the loaded samples

The online version of the original article can be found under doi:10.1007/s11043-009-9077-x.

R.K. Krastev (凶) · G. Zachariev · J. Hristova

Central Laboratory of Physico-Chemical Mechanics, Bulgarian Academy of Sciences,

Acad. G. Bonchev str., bl. 1, 1113 Sofia, Bulgaria

e-mail: r_krastev@netbg.com

J. Minster

Institute of Theoretical and Applied Mechanics, Czech Academy of Sciences, Prosecka str., 19000 Prague, Czech Republic 